\title{
Cheryl de la Rey Dedication - A tribute
}

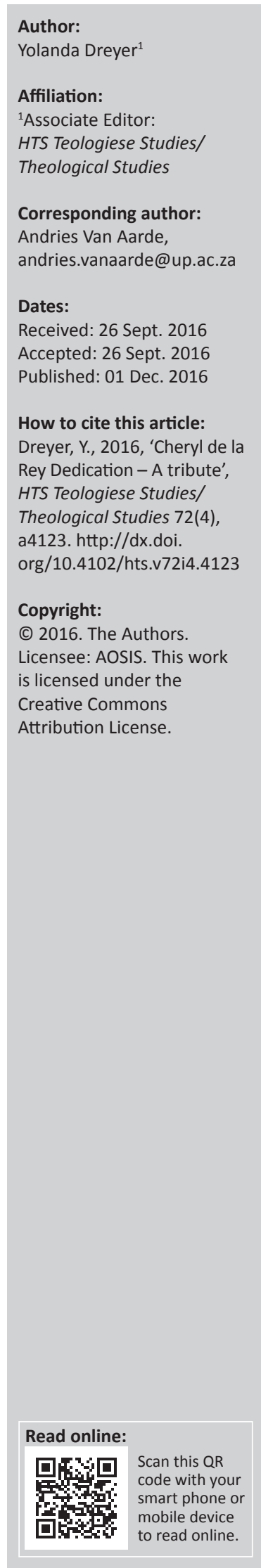

Professor Cheryl Merle de la Rey, vice chancellor and principal of the University of Pretoria since 2009, hails from Durban, KwaZulu-Natal. She matriculated from the Parkhill Senior Secondary School in Durban and received the degrees BA, BA (honours) and MA in psychology from the University of Natal (Durban). Her Masters dissertation was on the role of security of social identity in intergroup relations. The $\mathrm{PhD}$, which she obtained in 1999 from the University of Cape Town, was titled 'Career narratives of women professors in South Africa'.

After a stint as a secondary school teacher, she was appointed lecturer in psychology first at the University of Durban-Westville where she served for six years and then as lecturer, senior lecturer and associate professor in psychology at the University of Cape Town where she also served for six years. She was first co-editor and then editor of the South African Journal of Psychology for a period of three years. In 2000, she became the executive director of the National Research Foundation, after which she was appointed as deputy vice chancellor of the University of Cape Town in 2002. This position she held for 6 years. After a brief term as chief executive officer of the Council on Higher Education (CHE), she became the vice chancellor and principal of the University of Pretoria, 2009 to the present.

Professor de la Rey is a registered research psychologist, a member of the Psychological Society of South Africa, the Academy of Science of South Africa and the International Women's Leadership Association. She serves on a number of committees and boards, mostly related to tertiary education and research.

Her own research in the field of social psychology focuses on race and gender, which immediately brings to the fore issues of power. Her work on race and racism includes academic racism. Her work on gender focuses on the construction of gender, consciousness-raising against gender oppression, gender-based violence and abuse, on the one hand. As a student, she worked in the rape crisis system and gained first-hand experience of how many women across all social classes are confronted with a threat to their safety. On the other hand, given the direction her own life has taken, another focus of her gender work is on women's leadership, with topics such as gender and the construction of knowledge, how successful women in the public, corporate and business sectors cope, and how they often collide with the glass ceiling. Her contribution was not confined to research and theory. Few women are willing to pay the price that comes with shattering the glass ceiling. You were and have done so spectacularly. For that, we thank you.

Another research interest of Professor de la Rey is identity and intergroup relations. From the perspective of culture, power and difference, her work contributes to the reshaping, reclaiming and renegotiating of identity in South Africa. In the field of peace psychology, she published on reconciliation in divided societies and, combining this with her gender interest, also on women and peace-building in South Africa. In an interview with the Pretoria East Record on Woman's Day, 9 August 2015, she said: 'When women stand together they would make a powerful statement'. ${ }^{1}$

Ten years into democracy, she reflected on South African psychology, wrote on truth and healing, on the psychosocial rehabilitation of the country and on psychology and the public good in a developing society. Social issues addressed in her research included the death penalty, poverty alleviation through partnership and teenage pregnancy, among others. As her career moved from psychology to leadership in higher education, her work focused on issues such as science and technology, the employability of university graduates and the role of universities in shaping public policy. In 2012, she became the well-deserved recipient of Rhodes University's 'Psychology and Social Change Award'.

1.Pretoria East Record, 9 August 2015, 'Tuks vice chancellor on family, feminism and Women's Month'. 
Amidst the abundant evidence of a highly successful academic career, to which undoubtedly most of her time and energy were devoted, there are glimpses of the person Cheryl de la Rey and some of her special loves. Her love of nature: she is a trustee of the World Wildlife Fund. And her love of sports: she published some academic articles on women road runners and, in 2006, was the speaker at the Queensland Rugby Club in Brisbane, Australia, on the role of rugby in the South African national identity.

Appointed at the University of Pretoria a year after its centenary celebrations, she was the new and different face of the institution entering into its second century. In her inaugural address in 2010, she referred to religious institutions and universities as two of the oldest social institutions still surviving today. Survival is only possible if institutions are resilient and can adapt to change - 'through times of conflict and depression and times of peace and prosperity' (p. 2). ${ }^{2}$ South Africa does not only find itself in the flow of rapid global change but also has to deal with what she calls 'an additional level of change' (p. 3). Particular challenges are faced by this divided and fragmented society, with its great divide between wealth, innovation and religiosity, on the one hand, and poverty and crime, on the other (pp. 3-4).

To meet these challenges, Professor de la Rey has led the University of Pretoria to focus on human capital development so that graduates can be prepared for their role in constructing a more harmonious and equitable society. With the holistic approach of a psychologist, she sees education as more than academic training. It is also about the quality of the student's experience and graduates who are equipped for the rapidly changing world in which they will be making their contribution. Her goal has been:

to create an environment where we will re-evaluate some of our traditions, continue those of which all of us are proud, discontinue those that do not promote a culture of inclusivity and respect for human rights and, instead craft new socially inclusive future traditions. (p. 9)

The recent student unrest on university campuses is closely related to sociological factors such as demographic change and the need to transform how we think about knowledge and the institution. Since 1994 the ideal has been the democratisation of education. The objective is affordable and accessible education for people of all socio-economic sectors. The demand for free education and insufficient government subsidy result in an impossible situation. Professor de la Rey's life's work in sociology and psychology with her passion for social cohesion equipped her for authentic leadership in tumultuous times, however difficult the task.

After 100 years at the University of Pretoria, entering into its next century, the Faculty of Theology, with its vision of life in its fullness and mission of life-giving theology for all, hopes to be a gateway to such a future.

2.De la Rey, C.M., 2010, "Installation of vice-chancellor and principal speech, 16 April 2010'. UP Space: Delarey_paper_2010.pdf, viewed on 1 September 2016, at http:// repository.up.ac.za/dspace/handle/2263
It is with great appreciation and gratitude that we present this volume to Professor Cheryl de la Rey.

\section{Papers and publications: Professor Cheryl Merle de la Rey Publications}

\section{Books}

- 1997 (co-editor), Contemporary Issues in Human Development: A South African Focus, International Thompson Publishing, Johannesburg.

- 2001 (co-editor), Race, Racism, Knowledge Production and Psychology in South Africa, Nova Science Publishers, Huntington, NY.

- [2004] 2011 (co-editor), Psychology: An Introduction. Oxford, Cape Town.

\section{Chapters in books}

- 1991, 'Intergroup relations: Theories and positions', in D. Foster \& J. Louw-Potgieter (eds.), Social Psychology in South Africa, pp. 25-35, Lexicon Publishers, Johannesburg.

- 1997, 'On political activism and discourse analysis in South Africa', in A. Levett, A. Kottler, E. Burman \& I. Parker (eds.), Culture, Power and Difference: Discourse Analysis in South Africa, pp. 189-198, Zed Books, University of Cape Town Press, Cape Town.

- 1997 (co-author), 'Teenage pregnancy: A contextual analysis', in C. de la Rey, N. Duncan, T. Shefer \& A. van Niekerk (eds.), Contemporary Issues in Human Development: A South African Focus, pp. 33-43, International Thompson Publishing, Johannesburg.

- 1997 (co-author), 'Gender and Mental Health Policy Development', in D. Foster, Y. Pillay \& M. Freeman (eds.), Mental Health Policy Issues for South Africa, pp. 143-158, MASA, Cape Town.

- 1999 (co-author/editor), 'Challenging Academic Racism in South African Psychology', in K. Prah (ed.), Knowledge in Black and White: The Impact of Apartheid on the Production and Reproduction of Knowledge, pp. 7-28, CASAS, Cape Town.

- 1999 (co-author), 'Processes of Reshaping, Reclaiming and Renegotiating Identity in South Africa', in S. Bekker \& R. Prinsloo (eds.), Identity? Theory, Politics, History Volume 1, pp.67-94, Human Sciences Research Council, Pretoria.

- 2001, 'Reconciliation in Divided Societies', in D.J. Christie, R.V. Wagner \& D. Du Nann Winter (eds.), Peace, Conflict and Violence: Peace Psychology for the Twenty-first Century, pp. 250-265, Prentice-Hall, Upper Saddle River, NJ.

- 2001, 'Consciousness-raising groups as an intervention strategy against gender oppression', in M. Seedat (ed.), Community Psychology: Theory, Method, and Practice, pp. 309-323, Oxford University Press, Cape Town.

- 2001, 'Racism and the history of university education in South Africa', in N. Duncan, A. van Niekerk, C. de la Rey \& M. Seedat (eds.), Race, Racism, Knowledge Production and 
Psychology in South Africa, pp. 7-28, Nova Science Publishers, Huntington, NY.

- 2002 (co-author), 'Constructing race: Black women activists in the Western Cape', in N. Duncan, P. Gqola, M. Hofmeyer, T. Shefer, F. Malunga \& M. Mashige (eds.), Discourses on Difference Discourses on Oppression, pp. 77-101, Centre for Advanced Studies of African Society (CASAS), Cape Town.

- 2002, 'Schools: Role-players in the construction of gender', in K. Asmal \& W. James (eds.), Spirit of the Nation: Reflections on South Africa's Educational Ethos, pp. 139-143, SRC/ Department of Education/New Africa Education, Cape Town.

- 2003 (co-author), 'Women's leadership programs in South Africa: A strategy for intervention', in V.E. Franchi \& D. Duncan (eds.), Prevention and Intervention Practice in Postapartheid South Africa, pp. 49-58, Haworth Press Inc., New York.

- 2003 (co-author), ‘Racism: A Social Psychological Perspective', in K. Ratele \& N. Duncan (eds.), Social Psychology: Identities and Relationships, pp. 65-80, UCT Press, Landsdowne, South Africa.

- 2004 (co-author/editor), 'A brief introduction to research approaches in Psychology', in L. Swartz, C. de la Rey \& N. Duncan (eds.), Psychology: An Introduction, pp. 3-19, Oxford University Press, Cape Town.

- 2004 (co-author/editor), 'Sex and gender in society', in L. Swartz, C. de la Rey \& N. Duncan (eds.), Psychology: An Introduction, Oxford University Press, Cape Town.

- 2012, 'Narrative Analysis. The Encyclopedia of Peace Psychology', in D.J. Christie (ed.), Blackwell Publishing, London.

- 2014, 'Basic and applied research in psychology education and training: South Africa as a case study', in R. Silberstein, P. L-J Ritchie \& J. Pandey (eds.), Psychology Education and Training: A Global Perspective, pp. 182-188, Routledge, London.

- 2015, ‘Women's Advancement in Science and Engineering in South Africa', in W. Pearson, L.M. Frehill, C.L. McNeely, (eds.), Advancing Women in Science: An International Perspective, pp. 333-337, Springer, New York.

\section{Articles}

- 1991 (co-author), 'Understanding intra-group variations in prejudice - the role of perceived legitimacy and stability', South African Journal of Psychology, 21(4), 225-232.

- 1992, 'Culture, tradition and gender: Let's talk about it', Agenda 17, 25-28.

- 1993, 'Race and gender constraints in South African road running', Agenda 17, 78-86.

- 1993 (co-author), 'A Psycho-demographic survey of women runners', S.A. Journal for Research in Sport, Physical Education and Recreation 16(1), 25-33.

- 1994 (co-author), 'Psycho-social effects of the death penalty on families of prisoners on death row', Acta Criminologica: Southern African Journal of Criminology 7(2), 20-24.
- 1996 (co-author), 'Public attitudes towards the death penalty in South Africa: A life or death decision?', Acta Criminologica: Southern African Journal of Criminology 9(1), 108-113.

- 1996 (co-author), 'Fraternal relative deprivation: Cognitive versus affective components and protest orientation among Indian South Africans', The Journal of Social Psychology 36(5), 579-588.

- 1996 (co-author), 'Community-based peer groups as an intervention program for teenage mothers', Journal of Community and Applied Social Psychology, 6(5), 373-381.

- 1997 (co-author), 'Gender and race: Whereto psychology in South Africa?', Feminism and Psychology 7(1), 138-142.

- 1997, 'South African feminism, race and racism', Agenda, 32, 6-10.

- 1997, 'Social reconstruction, gender equity and psychology in South Africa', Psychology Bulletin 7(1), 9-12.

- 1997 (co-author), 'Challenging authorship and authority in psychology: A publishing initiative', Psychology in Society 22, 37-46.

- 1997 (co-author), 'Intragroup accounts of teenage pregnancy: A community-based psychological perspective', South African Journal of Psychology 27(4), 223-229.

- 1997 (co-author), 'Doing something active and positive about academic racism', South African Journal of Psychology 27(4), 210-205.

- 1998 (co-author), 'Shifting the publications game: The case of a textbook project at a historically black university', Perspectives in Education 17(2), 71-86.

- 1998 (co-author), 'Perceptions of Psycho-Social Healing and the Truth and Reconciliation Commission in South Africa', Peace and Conflict: Journal of Peace Psychology, 4(3), 257-270.

- 1998 (co-author), 'Gender and Relations of Knowledge Production in South Africa', Psychology Bulletin 8(1), $11-15$.

- 1999 (co-author), 'Societal transformation: Gender, feminism and psychology in South Africa', Feminism $\mathcal{E}$ Psychology 9(2), 120-126.

- 2000, 'Structural Asymmetries and Peace: Hope or Despair?', Peace and Conflict: Journal of Peace Psychology 6(3), 217-221.

- 2001 (co-author), 'Women's meanings of peacebuilding in post-apartheid South Africa', Peace and Conflict: Journal of Peace Psychology 7(3), 227-242.

- 2001 (co-author), 'Work-Family Interaction Strain: Coping Strategies used by Successful Women in the Public, Corporate and Business Sectors', South African Journal of Psychology 31(4), 55-61.

- 2002 (co-author), 'Peace as a Gendered Process: Perspectives of Women doing Peacebuilding in South Africa', International Journal of Peace Studies 7(1), 91-101.

- 2003 (co-author), 'Women's Leadership Programmes in South Africa: A Strategy for Community Intervention', Journal of Prevention $\mathcal{E}$ Intervention in the Community 25(1), 49-64. 
- 2003 (co-author), 'South African women leaders in Higher Education: Professional development needs in a changing context', McGill Journal of Education 38(3), 407-420.

- 2003 (co-author), 'He's a man, and I'm a woman: Cultural constructions of masculinity and femininity in South African women's narratives of violence', Violence against Women 9(8), 1003-1029.

- 2004 (co-author), 'Woman Abuse: The construction of gender in women and men's narratives of violence', South African Journal of Psychology 34(3), 443-463.

- 2004 (co-author), 'The call for relevance: South-African Psychology ten years after democracy', South African Journal of Psychology 34(4), 544-552.

- 2005, 'Gender, Women and leadership', Agenda 65, 4-11.

- 2006 (co-author), 'Peacebuilding as a gendered process', Journal of Social Issues 62(1), 141-153.

\section{Other publications}

- 1999, 'Understanding the convergence of subjectivity and socio-historical context through the career narratives of South African women academics', Winds of Change: Women and the Culture of Universities, Conference Proceedings, Vol. 11, 412-418.

- 1999, 'South African women in higher education: A review of their experiences', International Strategies for Building Research Capacity among Women in Higher Education Workshop Report, HSRC, Pretoria.

- 1999, 'Domestic violence: Naming and other conceptual issues', Women's Studies 11(1-2), 15-23.

- 2000, 'Career narratives of women professors in South Africa', to be viewed at, www.skk.uit.no/ww99/ proceedings/proceedings.html

- 2001, 'The Experiences of Women in Academia: Glass Ceilings in the Health Sciences Faculty?', in B. Klein, L. London, \& G. Perez (eds.), Manual for Transformation Workshops, Faculty of Health Sciences, University of Cape Town, Cape Town.

- 2001, 'Women and management in higher education in South Africa', ACU/IoE Seminar on Managing Gendered Change in Selected Commonwealth Universities, Johannesburg.

- 2004, 'Leadership for Reconciliation', Proceedings of the International Perspectives on Peace and Reconciliation Conference, 14-17 July, University of Melbourne, Melbourne.

- 2003, 'Turning the gaze on itself: Psychology as a site of social change in South Africa', in M. Katsikitis (ed.), Proceedings of the 38th Annual Conference of the Australian Psychological Society, 2-6 October 2003, Perth, 59-61.

- 2006 (co-author), 'High Performance Computing in South Africa: Computing in Support of African Development', CT Watch Quarterly: International Cyberinfrastructure: Activities Around the Globe 2 (1), 32-36.

- 2007, 'Beyond the Myth. Women in Science', Mail $\mathcal{E}$ Guardian 24 - 30 August.

- 2012, 'Viewpoint: Working for poverty, alleviation through partnership', WDB Voices.
- 2013, 'The evolution of thinking on universities and the social compact in South Africa, A year in review: 2012-2013', Inyathelo's Annual Report.

- 2014, 'Reshaping African PhDs for development', SciDev. net, 5 March.

- 2015 (co-author), ‘Position Paper: Business Graduate Employability and Higher Education Investment in Africa', Policy discussion paper submitted, The Continental Summit: Revitalization Higher Education for Africa's future.

- 2015, 'The Triple Helix: Cooperation between government, academia and business', Boa Review Magazine, July, 56-58.

- 2015, 'Should global league tables consider community engagement? Yes they should argue, Antony Monaco and Cheryl de la Rey', World University rankings blog, to be viewed at http://timeshighereducation.co.uk/blog/ world-university-rankings-blog-should-global-leaguetables-consider-community-engagement

- 2015, 'Preface', in S. Wild, Innovation: Shaping South Africa through Science, Pan Macmillan, Johannesburg.

- 2016, 'The Power of partnerships', ETH Global Lecture Series, ETH Zurich, to be viewed at https://www.ethz. ch/en/the-eth-zurich/global/eth-global-newsevents/2016/02/south-africa-meets-eth-zurich.html

- 2016, 'Women and leadership in higher education', Bulletin, Publication by the Association of Commonwealth Universities.

\section{Papers presented, keynotes delivered and addresses}

\section{Academic international conference papers}

- 'Seeking Truth and Healing: Psychosocial Rehabilitation in South Africa', paper presented at the 104th Annual Convention of the American Psychological Association, Toronto, Canada, August 1996.

- 'Conflict Resolution Techniques use by Women Mediators in a post-apartheid South Africa', paper presented at the XXVI International Congress of Psychology, Montreal, Canada, August 1996.

- 'Understanding the convergence of subjectivity and socio-historical context through career narratives of South African women academics', Winds of Change: Women \& the Culture of Universities, Sydney, Australia. July 1998.

- 'Taking Steps for Gender Equality: The Case of South Africa 1994-1998', 24th International Congress of Applied Psychology, San Francisco, United States of America, August 1998.

- 'Career Narratives of Women Professors in South Africa', Women's World's 99: 7th International Interdisciplinary Congress on Women, Troms, Norway, June 1999.

- 'Success Stories and Moral Tales: Career Narratives of Women Professors in South Africa', British Psychological Society Psychology of Women Section Conference, Dundee, Scotland, July 2000.

- 'Peace as a Gendered Process: Perspectives of Women doing Peacebuilding in South Africa', 18th General International Peace Research Association Conference, Tampere, Finland, August 2000. 
- 'Women and Leadership', Invited address, XXV International Congress of Applied Psychology, Singapore, July 2002.

- 'Psycho-social factors impacting on women in South Africa', XXV International Congress of Applied Psychology, Singapore, July 2002.

- 'Women and peacebuilding - Method matters', XXV International Congress of Applied Psychology, Singapore, July 2002.

- 'Leadership for Reconciliation', Invited address International Perspectives on Peace and Reconciliation Conference, University of Melbourne, Australia, July 2003.

- 'Asymmetries of power, interdependence and leadership', State of the Art lecture, 26th International Congress of Applied Psychology (ICAP 2006), Athens, Greece, July 2006.

- 'Empowerment of Women and Gender Equality: Lessons from South African Higher Education', Association of Commonwealth Universities Conference, Cape Town, South Africa, April 2010.

- 'The future of undergraduate education: Breath or Depth?', Second Annual Princeton-Fung Global Forum, Paris, France, April 2014

- 'Business, Graduate Employability and Higher Education Investment in Africa', Policy discussion paper submitted to the Continental Summit: Revitalizing Higher Education for Africa's Future by Tinyiko Maluleke, Natasja Holtzhausen, Cheryl de la Rey and Jennifer Mckellar, Dakar, Senegal, March 2015

\section{International and national keynotes and invited presentations}

- 'Power and Inequality in Psychological Knowledge in South Africa', Invited Keynote Address, 8th TransTasman Community Psychology Conference, Perth, Australia, June 2002.

- 'Turning the gaze on itself: Psychology as a site of social change in South Africa', Keynote Address, 38th Annual Conference of the Australian Psychological Society, Perth, Australia, October 2003.

- 'Measuring Research Quality and Impact: Implications for Research Managers', invited speaker, INORMS Internationalization of Research Congress, Brisbane, Queensland, Australia, August 2006.

- 'Policy on Postgraduate Studies', Presentation at the National Research Foundation UNISA Postgraduate Research Indaba, Pretoria, South Africa, February 2007.

- 'Recruitment and retention of women staff: Is there a glass ceiling in South Africa?', Invited speaker, Institutional Cultures and Higher Education Leadership: Where are the women?, Conference organized by HERS-SA, CHE, Department of Education and Higher Education South Africa (HESA), Cape Town, South Africa, March 2008.

- 'Opportunities for Universities of Technology in South Africa', Guest Speaker at the First Annual South African Technology Network Conference, Durban, South Africa, May 2008.
- 'The Challenges of Women in Research in Higher Education', Speaker at the Launch of the Women in Research Association (WIRA), Cape Peninsula University of Technology, Cape Town, South Africa, August 2008.

- 'Challenges facing South African Higher Education', Guest speaker at the St Augustine College Graduation Ceremony, Johannesburg, South Africa, August 2008.

- 'South Africa Experiences and Challenges in Developing the Next Generation of Academics', Invited presentation, University Leader's Forum, Accra, Ghana, November 2008.

- 'Relevance of Science and Technology Education for Economic Development', Keynote Address, launch of the Moses Kotane Institute, Durban, South Africa, January 2009.

- 'Psychology and the public good in a developing society', Psychology Society of South Africa Congress, Cape Town, South Africa, August 2009.

- 'The strategic role of Student Housing in the promotion of Student Development and Success', The Southern Association for College and University Housing OfficersSouthern African Chapter, Student Housing Annual Conference and Exposition, Durban, South Africa, August 2010.

- 'Ensuring Quality in Higher Education', Price Waterhouse Coopers Annual Conference, Port Elizabeth, South Africa, August 2010.

- 'Women in Higher Education: Not a straightforward story', HERS-SA Academy 2010, Cape Town, South Africa, September 2010.

- 'Gender Equity in the 21st Century', Oration at the Edith Cowan University, Perth, Australia, October 2010.

- 'Defining and Achieving Excellence in Postgraduate Training', Carnegie's Developing and retaining the next generation of African Academics: Excellence, Retention and Sustainability, Nairobi, Kenya, November 2010.

- 'University-Government-Industry relationships for research and innovation', HESA Research and Innovation Conference, Pretoria, South Africa, March 2010.

- 'The significance of Higher Education, Science and Technology in developing countries', Public Lecture, University of Technology, Jamaica, January 2012.

- 'Becoming the subject: Dilemmas for women leaders in Higher Education', Association of Commonwealth Universities Conference, Critical Women: Women as Agents of change through Higher Education, Colombo, Sri Lanka, March 2012.

- 'The role of Rugby: SA national identity', Queensland Rugby Club, Brisbane, Australia, March 2012.

- 'Basic and Applied Research in Psychology Education and Training: South Africa as a case study', Workshop on Psychology Education and Training: A Global Perspective, University of Jena, Germany, May 2012.

- 'Universities, Government and Industry: Changing Roles and Expectations', PWC Higher Education Conference, Cape Town, South Africa, September 2012. 
- 'Advancement in Africa: A Leadership Perspective', Educational Advancement in Africa Conference, Cape Town, South Africa, November 2012.

- 'Resilience, relevance and the role of Universities', Royal Society of SA, Pretoria Country Club, Pretoria, South Africa, September 2013.

- 'Bridging Dualisms in Contexts of rapid change: A challenge for Vice-Chancellors', Association of Common Wealth Universities Centenary Conference, University of London, United Kingdom, October 2013.

- 'Making knowledge work: the role of universities in shaping public policy', 9th National Public Policy Congress, Gold Coast, Australia, November 2013.

- 'Integration natural and social perspectives to address sustainability challenges', World Science Forum, Rio de Janeiro, November 2013.

- 'Opening address at the ASSAf Humanities Conference' with the theme, Living the world, reading the world, understanding the world: The Humanities reach out, CSIR, Pretoria, South Africa, June 2014.

- 'Education, science and technology in Africa: Creating a synergy to generate jobs and create wealth', Australia Africa Universities Conference, Australia National University, July 2014.

- 'Business, HigherEducation and GraduateEmployability', Panel Member, African Higher Education Summit, Revitalizing Higher Education for Africa's Future, Dakar, Senegal, March 2015.

\section{References}

De la Rey, C.M., 2010, 'Installation of vice-chancellor and principal speech, 16 April 2010', UP Space, Delarey_paper_2010.pdf, viewed 1 September 2016, from http://repository.up.ac.za/dspace/handle/2263

Pretoria East Record, 'Tuks vice chancellor on family, feminism and women's month', viewed 9 August 2015, from http://rekordeast.co.za/59925/tuks-vice-chancelloron-family-feminism-and-womens-month/ 